\title{
Views of mothers on the fundamental role of the Christian father as mentor in a nuclear family environment
}

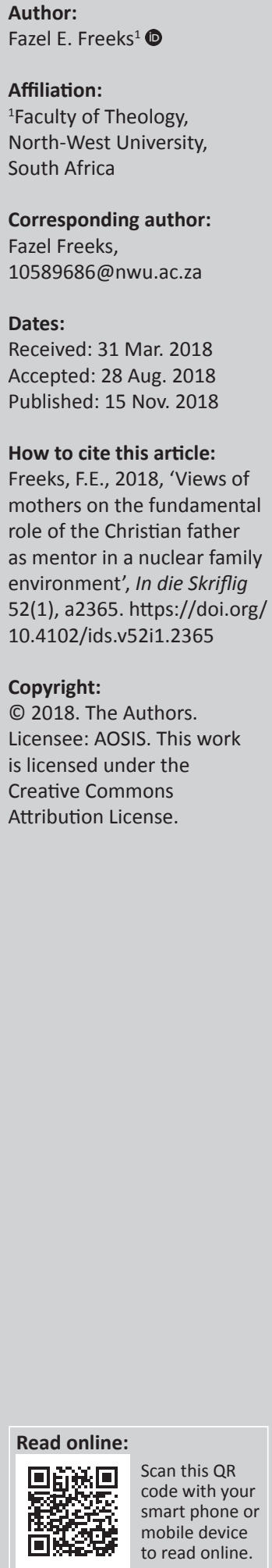

\begin{abstract}
The present empirical study explored and described the views of mothers elicited through in-depth interviews. This research followed an explorative, interpretive and descriptive qualitative design by using purposive voluntary sampling. Mothers were selected by their lived experience and knowledge of the father absence problem, leadership, prominence in society, and involvement in their community. Data was collected through in-depth interviews, and field notes were taken. The data was analysed through open coding. The results of the empirical research in which mothers were involved indicated that the Christian father as mentor is deemed crucial and relevant within current families. Mentoring by the father is vital in the lives of children and should be implemented and emphasised within the family context. As mentor, the father should nurture the children spiritually and shape their character, thus helping them become complete, whole and, by the grace of God, holy 'before God' (coram Deo).
\end{abstract}

\section{Introduction and problem statement}

The present study focused on mothers' views of the fundamental role the Christian father plays as mentor within a nuclear family environment. This study forms part of a previous article about the way adolescents respond to the indispensable role of the Christian father as mentor within the family (Freeks 2017).

For this article, mothers expressed their views on crucial matters such as the absenteeism or presence of fathers, their responsibility, involvement and the respect they attain. This includes fathers' role modelling, importance in the family set-up as well as guidance in sexual matters. The participants also focused on the importance of God, the godly role of the father, politics, government and the fact that men lost their way regarding family life.

Globally, dysfunctional family life is a major issue with the father's absence and fatherlessness forming the core of the problem (cf. Carstens 2014:10). Father absence is a tendency across communities (Bartlett 2013:1-3; Dobbs 2013:2; Williams 2014). Research confirms repeatedly that fatherhood is essential within the family environment. Thus, the father figure still fulfils a unique role in the development of the children's behaviour, life choices, relationships and self-esteem (cf. Vaughan 2010; Waresak 2016).

Currently in South Africa, it is estimated that 2.13 million children are growing up without a father (Dube 2016:2). These statistics present an immense challenge to fatherhood within the country. South Africa is rapidly becoming a fatherless society where men mistreat women and children (cf. Feni 2016:2). The family is redefined with the father not even present (cf. Ford et al. 2008). Furthermore, 1.1 million births were registered in 2015 and $64 \%$ of cases indicated that there is no information about the biological father. In 2015, approximately 886202 babies were born and $50 \%$ of the women were single mothers who received no assistance from the biological father (cf. Frazier 2015; Hawkins 2015; Mkhize 2013:2).

Fathers should not only provide financial aid. Their value within the family should thus not be measured by material provision. It should rather be assessed by the love and attention which fathers provide to their family (Williams 2008:18). It is important to note that boys are looking for a father figure as a role model. It does not necessarily have to be their biological father, but one who leads by example and, in the mentoring process, acts as a role model to them (cf. Freeks 2011). This will enable the boys to accept their own role of fatherhood in future 
(Goeke-Morey \& Cummings 2007:221-225). Most of the literature that was studied referred to boys. However, several authors and researchers point out that girls are closer to their fathers and look up to them as role models (e.g. Fagan et al. 2009:1390-1391; Goodsell \& Meldrum 2010:250; Perrin et al. 2009:314; Willerton et al. 2011:521; Wong, Mcelwain \& Halberstadt 2009:454).

Based on the discussion above, there is evidently a dilemma regarding the effects of the 'absent' father. In most cases the father is present, but is experienced as unavailable, unsupportive and uninvolved in the family set-up. Relationships with others become a challenge, as it may be broken. A sound relationship involves attributes such as motivation, encouragement, nurturing and teaching (Johnson \& Ridley 2004:xv). Needless to say, in several instances the father is absent as role model and mentor in the lives of children. The aim of this article is contributing to the field of Practical Theology specifically as research and interest towards community engagement.

\section{Research objective}

The objective of the present research was to explore and describe the views that mothers hold about the fundamental role the Christian father plays as mentor within a nuclear family environment.

\section{Research design}

This article followed an exploratory, interpretive and descriptive qualitative research design (Thorne 2008, cf. De Vos 2005:333-334; De Vos, Schurink \& Strydom 2001:15; Mouton \& Marais 1992:45). Linked to this approach, the model of Lotter (2007:4) was used. Although this model is applied to Pastoral Theology, Lotter has not developed a theoretical framework to explain his meaning of Pastoral Theology. This is therefore a lacuna that may be filled or expanded on in future research.

The phenomenon that was explored, described and interpreted is the Christian father as mentor within a nuclear family environment (cf. Freeks 2011:113; 2017:2). The context of the present study (Freeks 2011) was the Tlokwe Municipality comprising the three traditional groups, namely people of mixed race, black and white people who reside in this municipal area. These groups are situated in Promosa, Ikageng and the greater Potchefstroom area. In these households, there are examples of absent fathers, drug and alcohol abuse, violence as well as unemployment. Mothers participated in the study due to their involvement and interest in the field.

\section{Research method}

The method of research employed for data gathering was in-depth interviews with mothers who live in a nuclear family environment (Botma et al. 2010:204-206). A detailed discussion under the section of data gathering explains how the interviews were conducted.

\section{Permission to conduct research}

Permission to conduct in-depth interviews with mothers was granted by the Research Committee of the Faculty of Theology and the Ethics Committee of the North-West University, Potchefstroom Campus (cf. Freeks 2011; 2017:2). Informed consent was given by the mothers (cf. Botma et al. 2010:12, 16-17).

\section{Sample \\ Sampling}

The article utilised purposive voluntary sampling. In the case of purposive sampling, the choice of the mothers was made based on their knowledge of and experience of the phenomenon. They also represented the characteristics or attributes needed for the study (cf. Babbie \& Mouton 2001:166-167; De Vos 2005:202). This group of mothers was selected, because they were involved in the community through prominent roles and thus showed leadership. Furthermore, the group was chosen carefully according to certain criteria (cf. Janse van Rensburg 2009:8; Neuman 2003:210; cf. also Freeks 2017:2). The following inclusion criteria were used for the mothers (Strydom 2005:206; cf. also Freeks 2017:2):

- They should be mothers within a nuclear family environment.

- In a nuclear family environment, these mothers must have children.

- They should be confessed Christians and be involved in church activities such as parent programmes, woman groups or women outreach.

- They must provide informed consent to participate in the study.

- They must be able to express themselves verbally in English or Afrikaans.

- They must give consent for the interviews to be voice recorded.

\section{Population}

As was explained previously, the population for the research consisted of a group of mothers ${ }^{1}-$ in this case, five - who belong to a nuclear family. These participants were respectively 40, 42, 53, 54 and 55 years old. They showed specific characteristics such as faith in God, respect and love for their fellow humans, self-confidence, dedication and measurements of interest (cf. Babbie \& Mouton 2001:175; Burns \& Grove 2005:355; Struwig \& Stead 2001:118). Mothers were recruited from the Promosa and Ikageng areas in Potchefstroom. The demographic layout of the Tlokwe municipal area is as follows: black people traditionally living in Ikageng, people of mixed race in Promosa, and white people within the greater Potchefstroom area.

\section{Data gathering}

The researcher identified the mothers in their community. These candidates were contacted by telephone to arrange an 1.When referring to this group of mothers, the term participants will be used further on. 
appointment for individual, in-depth interviews. Aspects such as confidentiality, privacy, risks, withdrawal and even possible termination of participation were discussed (Botma et al. 2010:13-14, 17, 22-24). The physical setting where the in-depth interviews were conducted was at the participants' homes or at a venue of their choice. The settings were private, pleasant and comfortable with little or no distraction (Pinkoane 2005:293; cf. also Freeks 2017:3).

Only four open-ended questions were formulated to ensure similar exploration of the participants' responses (Botma et al. 2010:134-135). The questions for the interviews were formulated clear, appropriate and understandable.

An audio-tape recording was used to ensure the information was captured well. The voice recorder was placed where it did not cause distractions during the interview. The goal of this research was to understand the mothers; thus, rapport was established during the interviews by a cordial and open atmosphere where participants did not feel threatened or uneasy (cf. Botma et al. 2010:208; Fontana \& Frey 2000:655). Communication techniques such as paraphrasing, reflecting, summarising, probing and clarifying were employed, and minimal verbal responses were sought (De Vos et al. 2001:289-290). After the interview concluded, the participants were asked whether they had anything to add besides the posed interview questions. Most of them added meaningful and relevant information (cf. Freeks 2017:3).

The following questions to the participants formed part of the inclusive criteria:

- Tell me about your experience of having been mentored as a child or young person, either by your father or a father figure.

- Tell me how would you like to see the role of the Christian father as mentor in the family environment?

- Tell me about your views of how you would like your husband, as the father of the family, to function as a mentor in the home.

- Anything else you would like to add to our discussion?

After each interview, field notes were taken that describe the 'what?', 'where?', 'who?' or 'how?' of the interview. This included written accounts of what the researcher felt, heard, saw, thought and experienced during the interview and were used for verification (Botma et al. 2010:217-219). These field notes were ordered into personal, observational and methodological notes (cf. also Freeks 2017:3).

\section{Data analysis}

The voice recordings were transcribed verbatim (Botma et al. 2010:214-215, 227-230; cf. Greeff 2005:298). The analysing method of open coding, as described by Cresswell (2009:185-187), was used. The following steps were taken: first, the data for analysis were organised and prepared. Thereafter, the data were compared with the field notes to ensure their meaning was represented correctly.
An independent co-coder was used for the data analysis (cf. Botma et al. 2010:2-4).

\section{Trustworthiness}

Trustworthiness was maintained during this research. The researcher ensured credibility and accuracy by comparing the research detail to the data obtained. Data of interviews were thoroughly written down. They were also recorded and reproduced correctly. The present study used the model of Lincoln and Guba (as cited by Krefting 1991:215, 222) which was summarised by Klopper (2008:70) and tabulated by Botma et al. (2010:232-235). The main aspects that were covered are epistemological standards such as truth value, applicability, consistency and neutrality. Trustworthiness was ensured by implementing the strategies of credibility, transferability, dependability and conformability (Botma et al. 2010:234-235, cf. also Freeks 2011:123; 2017:3).

\section{Mentoring}

The views of mothers about the way mentoring emerges in the role of the father was crucial for this research. The participants identified core aspects such as responsibility, involvement and the affectionate role of the father towards his children as fundamental to the mentoring process. Furthermore, mothers suggested that it should be a priority for fathers to spend time with children, because it promotes healthy relationships and strengthens the bond between them (cf. Freeks 2011:145-165, 176-177).

Over the past few years there has been an increase in focus on mentorship. This took place in the field of education, the business sphere, health field, e-mentoring, Practical Theology, pastoral narratives as well as in the family dimension (Fourie \& Van den Berg 2007:94-95; Lotter 2010:6; Masango 2011:3-4; Steytler 2007:12).

To link and fit such a present-day concept as mentoring within the paradigm of family life, it is necessary to explain this concept. Various authors provide numerous explanations and definitions of mentoring - as is shown below.

Tucker (2007:iii, vi) gives an appropriate and applicable explanation and definition that supports the basic line of argument followed in the present article. According to his view, mentoring entails relationships and unleashes people's potential which allows them to function optimally within their environment. He adds that mentoring is a supportive, learning relationship in which an individual, the mentor, shares his or her knowledge, experience and insights with another, less experienced person - the learning associate ('mentee'). The latter is willing and ready to benefit from this exchange.

De Long, Gabarro and Lees (2008:115-121) point out that mentoring is personal and should provide frequent and fair authentic advice and nurturing. This may also entail the offline help by one person through significant transitions in 
knowledge, work or thinking (cf. Allen \& Eby 2007:9-12; Corey \& Corey 2007; Derrick \& Dicks 2005:9-10; Herman \& Mandel 2004:1-2; Johnson \& Ridley 2004:xv; Megginson et al. 2006:4-5; Mulaudzi, Libster \& Phiri 2009:49; Rudney \& Guillaume 2003:2).

Steytler (2007:39), in turn, views a mentor as an older individual who does not only believe in the younger person, but also leads and empowers him or her. Such a mentor maintains an open relationship with the younger person to develop trust between them. These mentoring relationships may, at times, be complex. However, in essence it entails the everyday interactions through which growth and development occur (Wood \& Duck 2006:156).

Mentoring should not be limited to a specific age as Steytler proposed. Instead other elements should be initiating factors such as the skills or experience of the mentor over the mentee (Steytler 2007:39). Mentoring thus means pairing a more experienced individual with a less experienced one. Through this relationship, the mentees with less experience or skills are capacitated. Applied to the nuclear family, children are able to develop their capabilities through the guidance and support of a more seasoned person such as the Christian father (Masango 2011:3-4; Wood \& Duck 2006:156).

In light of the discussion above, proper mentoring with a longer duration may even go beyond the basic definitions. This action may lead to a mature friendship and reciprocal guidance as the researcher has experienced in his field of study.

Furthermore, it became clear that the above-mentioned aspects of mentoring may be applied to the Christian father as mentor within the family. For example, fathers may help their children to learn the basics of 'walking with Christ' (disciple). They may assist their children to mature in their Christian life (spiritual guide). Fathers may also help children to function independently, for example to apply and get admission to a university. They can provide assistance to their children with studies (coach). A further way is to give sound advice that will help the children navigate difficult situations and challenges in life (counsellor). The father should also inculcate the essential ideas and help children find perspective in life to make appropriate and quality decisions for their own lives. Thus, the father (mentor) should be a guide who helps the child (mentee) to find the right direction in life (teacher) (cf. Freeks 2017:3-4).

\section{Ethical consideration}

The present study followed the prescribed ethical considerations. Firstly, the mothers were approached and their involvement and participation explained to them (cf. Freeks 2017:3). Further ethical considerations, namely the right to self-determination, privacy, confidentiality, and assured fair treatment were also explained to the participants beforehand (Brink 2007; Burns \& Grove 2005; Strydom \& Delport 2004; cf. also Freeks 2017:3).

\section{Results of the study}

The results obtained from the participants are discussed below. Richness is provided by verbatim quotes and a literature control to validate the findings. The purpose of literature control is to compare the findings of the study with existing literature and draw relevant conclusions (cf. Botma et al. 2010:196-197; cf. also Freeks 2017:4).

\section{Results from in-depth interviews with the participants}

During the data analysis, 13 themes emerged from the participants' responses. These themes are expounded below.

\section{Theme 1: The absent father}

The participants indicated that the absent father is a disadvantage in households. They expressed their feelings as follows: 'If there is no father figure it has a negative influence on the children'; 'The absent father is a disadvantage'.

These findings are supported by Palkovitz (2007:195), Williams (2008:18), and Freeks and Lotter (2009:520-521). They point out that absent fathers cause tremendous pain and suffering in homes. Thus, society is placed in a dilemma due to the absence of fathers in the lives of children. Steytler (2007:36) concurs and indicates that the absent father has an undeniable effect on sons by, for example, causing a poor self-image. Fathers' absence has a direct influence on the social functioning of sons when these fathers are unemployed and uninvolved in the lives of their own children (Steytler 2007:37-38). Furthermore, sons experience identification problems and daughters are under severe pressure because of absent fathers (cf. Seutter \& Rovers 2004:43-45). The absent father does not only cause problems in a home or community - the entire nation could be adversely affected by father absence (cf. Freeks 2004:2-3).

\section{Theme 2: Fathers should be present}

For the participants it was important that fathers should be present in the lives of their family. They emphasised that fathers introduced certainty and knowledge in the home, and would ensure that household processes run smoothly. The participants elaborated: 'The father must be present in the home'; 'Most of the things in the house should be done by the father'; 'When he is there, we could pull some strength from him'.

These responses above are in accordance with findings from Steytler (2007:55-56). He indicates that fathers should be present in the lives of their children who must be directed, empowered and their best qualities brought forward (cf. also Williams 2008:18). Freeks and Lotter (2009:530) also stress that fathers should be present so that families can be restored and function stably in society. In this way, children can experience the love, intimate bond, protection and clear direction in life which make them effective and productive in their own lives (cf. Williams 2008:18). Barker (2008:5) points 
out that the present and involved father plays a major role in the development of the children. Such a father role is meaningful and significant for the growth and characterforming of the child (cf. Olsen 2007:174-177).

\section{Theme 3: Fathers should fulfil a more responsible role in their families}

The participants also emphasised that fathers should take more responsibility for their family. This is evident from responses such as: 'Fathers should interact more with their children because interaction is very important in the household'; 'Fathers need to have expectations with regard to his family'.

These findings find support in Coakley (2006:154). He states that the father should interact more with his children to promote their success. Wall (2007:59) explains that fathers should have certain expectations for their children and plans for their future. Thus, responsible fathering provides in the needs of the children and accomplishes success (cf. Freeks 2004:58).

\section{Theme 4: The husband should be more involved}

The participants emphasised that the father should be more involved as husband in the home environment. This need was expressed as follows: 'A dad should be more involved, especially with boys positively, and not destructively but in a joyous but strict manner'.

This finding is in accordance with that from Krampe and Newton (2006:159-161). They indicate that such involvement shows a father presence, leading to happy families which reflect the love of the father as his overall involvement. Warren (2005:53) and Pleck (2007:196) point out that father involvement forms part of his responsibility and commitment towards the family; thus, children benefit through such interaction.

\section{Theme 5: The father as teacher at home assures respect}

The participants also mentioned that the impact of the father as a teacher introduces a natural authority into the home environment. This perspective was verbalised as follows: 'The father as teacher prevent[s] disrespect in the home'; 'He needs to teach how to handle issues'.

In this regard, McGraw (2004:10) points out that parents (fathers or mothers) are the first teachers who train their children in positive ways which are necessary to become effective individuals in life. In the same vein, Heenan (2004:3) views parents (fathers or mothers) as the first and most important educators of values (cf. also Freeks 2007:81). When fathers teach their children, they also discipline them (cf. Munroe 2008:123).

\section{Theme 6: The father as a role model for education within the community}

The participants emphasised that their husbands should be role models within their community. However, they also mentioned that fathers are afraid to fulfil that role due to the added responsibility. The following excerpts from responses elaborate on this matter: 'Our husbands are principals of schools'; 'They are great role models to the teachers and children'; 'He applauded, encouraged, and motivated them in their studies'; 'Fathers are rather standing backwards because they are afraid of failure of being a role model in the household'; 'The world and the media represent the role of the father as distorted'.

In literature, these findings find support from Blackthorn (2004:5). He explains that children are looking up to people to whom they can relate and try to emulate. He adds that children look up to parents as an example of how to behave. Freeks (2004:102) concurs and views the father as ideal role model for the children who learn from his behaviour and attitude. According to Steytler (2007:54), the father is the natural role model and children seek someone with whom they can relate and identify.

Regarding education, Ellis, Cogan and Howey (1991:120) view this as one of the most important activities in which human beings engage. According to them, education is one of the major strategies through which people attempt to change or improve their societies. Thus, education produces growth, development, self-reliance, maturity and moral freedom. These tenets realise in the physical, psychological, social and religious dimensions of the living world (Abdool 2005:44; Rens 2005:29). In this regard, Coakley (2006:154) raises the issue that fathers who do not advocate the interests of their family actively can be considered as failing to meet the standards for good parenting. He stresses that fathers should be committed and responsible within the home environment.

\section{Theme 7: Children need fathers and should understand the indispensability of the father}

It was important for the participants that every child has a father figure, especially the young boys and girls. They emphasised that the presence of the father is crucial and children should understand the importance and indispensability of such a figure. The participants explained as follows: 'Children need their fathers for social support'; 'Boys want to be like their fathers'; 'Boys want to follow in their fathers' footsteps'; 'The father should be there to show how to handle tragedies in life'; 'Children should not be raised independently, they need the love of the father'.

These findings find support from various researchers. Williams (2008:1-3), for example, asserts that there is globally a need for good fathers. He adds that fatherhood will continue to have a lifetime impact in children's lives and should be revered and approached with a sincere passion. Thus, if parents provide mentoring, families will experience fewer problems with emotional baggage. Steytler (2007:55) recapitulates: children need a father who can fulfil their lives.

Barker (2008:5) emphasises the indispensability of the father according to which fatherhood and being a sound provider is 
one of the most important aspects. Thus, the presence of a father in the family is imperative. A father's mere presence implies a physical availability within the family set-up. Wall (2007:54) and Coakley (2006:154) view the father's presence as being active in the home environment. Olsen (2007:175-176) points out that when the father is not at home, children call out with a non-verbal voice: 'Daddy, come home!' Williams (2008:18) puts the concept of a father's indispensability into perspective. In this regard, a father has a desired quality, namely the ability to instil traits in the lives of children, helping them develop into productive and successful adults.

\section{Theme 8: The father should communicate the aspect of sexuality to children}

The participants felt strongly during the interviews that not only mothers should discuss matters of sexuality with their children; fathers should also. The father should especially translate the matter to young boys, as certain aspects relate closer to fathers than to mothers. The participants expressed their feelings and views as follows: 'The father needs to talk about the sexuality aspect with his son'; 'They need to know how to treat girls'; 'Boys are not supposed to sleep with girls until they made a commitment so that no children are born out of wedlock'.

These findings are in line with those of Bergh (2002:83). He points out that the father must communicate sexuality due to his paramount role in the sexual identity of the child.

\section{Theme 9: The importance of God within the family}

The importance of God within the family set-up was deemed crucial for the participants. They asserted that God is the first priority within a family. This is attested to by the following excerpts: 'God is priority and comes first in everything'; 'Families are important in the eyes of God'; 'Fathers should know that God comes first in everything because families with a strong religious background result from the position of the father figure'.

Dickie et al. (2006:58-59) view closeness to God when children perceive him as 'Father God'. Bergh (2002:110) emphasises that parents should teach their children about God's truths as well as lead and direct them to discover their own faith in God. Munroe (2008:25-31) elaborates and explains that God is important in the lives of a family, because the Fatherhood of God is the original image of earthly fatherhood, from which it derives its true meaning. Thus, the identity of families is established in Christ. Therefore, families should realise that God takes priority and is important within the family environment.

\section{Theme 10: The godly role of the father within the family}

According to certain participants, the father has a godly role within the family. Thus, fathers should practise their way of living based on a biblical perspective and apply it practically within in the family environment. The participants verbalised this dimension as follows: 'It is important for children to see the godly role of the father'; 'Fathers should first have love for God and then they will have love for their family'; 'He [the father] should teach his children how to communicate with God'; 'He should demonstrate that children should rely and depend on God when they experience a crisis'.

These findings resonate with those of Scalise (2010:56). According to him, the father should demonstrate a godly character as a follower of Christ; thus, presenting certain attributes such as humility, gentleness and patience towards his wife and children. Furthermore, the father should cultivate a passion for the love of God and should implement Bible studies, house altar, cell church and prayer meetings at home with his family. Bergh (2002:176) points out that the church is responsible to equip, guide, serve and support fathers helping them to grow spiritually for their godly role within the family.

\section{Theme 11: Politics as obstacle to fathering and mentoring}

The participants mentioned that politics are introduced into the family environment. This creates severe challenges for fathers, especially when having to deal with the rights of children. The participants explained: 'Freedom is granted to children who misused and misunderstood it'; 'Rights go with responsibilities, especially in the context of the home'; 'Women are now playing a bigger role, especially in politics'.

The findings above are in line with those from Steytler (2007:33). He points out that men are no longer necessarily acting as breadwinners within the family, seeing that the role of women has changed drastically on corporate levels. Female roles are emphasised and more attention is paid to women and children. The progress of women in the corporate world and the decline of men in higher management positions also reflects as a change in the family system.

Taken to the extreme, certain feminists believe that men can be considered a luxury in the family. This opinion has not yet appeared in recent references (cf. Erickson 1996:39). One of the negative consequences is that fatherhood moved to the background with the focus and emphasis more on the career world, whereas it was supposed to be on the family.

\section{Theme 12: The Government as obstacle to fathering and mentoring}

Certain participants felt that the Government is dictating values to families. As a result, certain important aspects of family life are taken away from households. They explained their views: 'Families have to adhere to Government'; 'Families should not allow Government to dictate certain things because it is not Government's function to dictate how to treat somebody else'; 'The function belongs to the home and church'.

In literature, these findings find support from Carl and De Klerk (2001:21). They point out that the government began a value education process in schools. However, the values on which the focus fell were nation building, democracy and human rights, aiming to overcome inequalities and 
injustice of the previous apartheid dispensation. These values are, thus, based more on governmental matters and not on families.

Bergh (2002:171) points out that the Government is concerned with the moral condition of the country as a whole. He reminded of the previous and late president, Nelson Mandela, who described South Africa morally as a sick society. According to Bergh, the church should join hands and negotiate with the Government on local, provincial and national level to highlight the existing contradictions with a view to balance them.

\section{Theme 13: Men lost their way}

The participants felt that men have lost their way and currently are unsure due to the effect of feminism. Some of them stated: 'Our men lost their way'; 'Men are feeling inferior towards women because women are earning more salary than their husbands'; 'Some men lost their certainty in the family'; 'Men lost their knowledge about their role as father'.

These findings link to those of Bergh (2002:84). He indicates that confusion reigns more in the modern milieu of family life, especially within the area of the husband's role in marriage. He adds that men find it difficult and are unsure of their role and therefore they negate their role as father. Freeks (2004:55, 95-98) concurs and emphasises that the community accepts the role of the father as an authoritarian position and worthy according to the biblical testimony on this theme.

\section{Findings}

The findings mainly suggest that the Christian father should be present throughout, as he has an important role to fulfil within the family environment. Fathers should not only be present, but also involved in and responsible for the lives of the children. Furthermore, fathers should act as role models to other people besides their own family. A further finding was the importance of God within the family and the godly role the father should play within this context. The inference can be drawn that fathers should first love God and then have love for their family. Other essential findings were the obstacles in the way of the fathering role. These impediments included politics, the Government and the changed role of the mother in the family. Such obstacles may cause that the role of the father within the family set-up is disrespected.

\section{Conclusion}

The overall view of the participants was that the father should be more involved in family matters. As figurehead, fathers should be more responsible in their role, tasks and obligations within a nuclear family environment. With the help and support of the mother, the father's role will be more functional and appreciated in the family. Fathers' children will look up to them as their ideal role model and mentor in life.

\section{Acknowledgements Competing interests}

The author declares that he has no financial or personal relationships which may have inappropriately influenced him in writing this article.

\section{References}

Abdool, A.D., 2005, 'Die waarde-oriëntering van leerders in sekondêre skole', PhD.proefskrif, Noordwes-Universiteit, Potchefstroom.

Allen, T.D. \& Eby, L.T., 2007, The Blackwell handbook of mentoring: A multiple perspectives approach, Blackwell Publishing, Malden, MA

Babbie, E. \& Mouton, J., 2001, The practice of social research, Oxford University Press, Oxford.

Barker, C.J., 2008, 'James Bernard: Fatherhood means leadership and commitment', New York Amsterdam News, 99(25), 5, Dec.

Bartlett, E., 2013, 'Die impak van afwesige vaders op adolessente meisies se psigososiale welstand', Hons. skripsie, Noordwes-Universiteit, Potchefstroom.

Bergh, S.J., 2002, 'Gesinsbediening as 'n geïntegreerde deel van die opbou van die gemeente', D.Th.-proefskrif, Universiteit van die Oranje Vrystaat, Bloemfontein.

Blackthorn, S., 2004, The parent's guide to parenting, Wiley, Indianapolis, IN.

Botma, Y., Greeff, M., Mulaudzi, F.M. \& Wright, S.C.D., 2010, Research in health sciences, Clyson Printers, Cape Town.

Brink, H., 2007, Fundamentals of research methodology for health/care professionals, 2nd ed., Juta, Cape Town.

Burns, N. \& Grove, S., 2005, The practice of nursing research, conduct, critique and utilization, 5th edn., Elsevier Saunders, St. Louis, MO.

Carl, A.E. \& De Klerk, J., 2001, 'Waarde-opvoeding in 'n jong demokrasie en Kurrikulum 2005: Panasee of mynveld', Tydskrif vir Geesteswetenskappe 41(1), 21-32, Maart.

Carstens, C., 2014, The world needs a father: A trainers' guide, Paarl Media Printers, Cape Town.

Coakley, J., 2006, 'The good father: Parental expectations and youth sports', Leisure Studies 25(2), 153-163, April. https://doi.org/10.1080/02614360500467735

Corey, M.S. \& Corey, G., 2007, Becoming a helper, Thomson, Brooks/Cole, Belmont, CA.

Cresswell, J.W., 2009, Research design: Qualitative, quantitative, and mixed methods approaches, 3rd edn., SAGA Publication, Los Angeles, CAL.

De Long, T.J., Gabarro, J.J. \& Lees, R.J., 2008, 'Why mentoring matters in a hypercompetitive world', Harvard Business Review 86(1), 115-121, Jan.

Derrick, J. \& Dicks, J., 2005, Teaching practice and mentoring: The key to effective literacy, language and numeracy teacher training, National Institute of Adult Continuing Education, Leicester.

De Vos, A.S., 2005, 'Qualitative data analysis and interpretation', in A.S. De Vos, H. Strydom, C.B. Fouché \& C.S.L. Delport (eds.), Research at grass roots, for the social sciences and human service professions, pp. 200-334, Van Schaik, Pretoria.

De Vos, A.S., Schurink, E.M. \& Strydom, H., 2001, 'The nature of research in the caring professions', in A.S. de Vos (ed.), Research at grass roots: A primer for the caring professions, 3rd edn., pp. 3-22, Van Schaik, Pretoria.

Dickie, J.R., Ajega, L.V., Kobylak, J.R. \& Nixon, K.M., 2006, 'Mother, father, and self: Sources of young adults' God concepts', Journal for the Scientific Study of Religion 45(1), 57-71. https://doi.org/10.1111/j.1468-5906.2006.00005.x

Dobbs, P., 2013, 'The impact of fatherlessness on the way one relates to God as Father', MA Dissertation, University of Otago.

Dube, D., 2016, '2.13 million kids in SA fatherless', viewed 20 June 2018, from http:// www.ann7.com/2-13-million-kids-in-sa-fatherless/

Ellis, A.K., Cogan, J.J. \& Howey, K.R., 1991, Introduction to the foundations of education, Allyn \& Bacon, Boston, MA.

Erickson, B.M., 1996, 'Men's unresolved father hunger: Intervention and primary prevention', Journal of Family Psychotherapy 7(4), 37-62. https://doi.org/10.1300/ J085V07N0403

Fagan, J., Palkovitz, R., Roy, K. \& Farrie, D., 2009, 'Pathways to paternal engagement Longitudinal effects of risk and resilience on non-resident fathers', Development Psychology 45(5), 1389-1405. https://doi.org/10.1037/a0015210

Feni, L., 2016, 'Forum raises concern over fatherless society', Daily Dispatch, 21 March, p. 2.

Fontana, A. \& Frey, J.H., 2000, 'The interview: From structured questions to negotiated text', in N.K. Denzin \& Y.S. Lincoln (eds.), Handbook of qualitative research, pp. 645-672, SAGA, Thousand Oakes, CA.

Ford, J.J., Nalbone, D.P., Wetchler, J.L. \& Sutton, P.M., 2008, 'Fatherhood: How differentiation and identity status affect attachment to children', American Journal of Family Therapy 36(4), 284-299. https://doi.org/10.1080/01926180701647074

Fourie, M. \& Van den Berg, J.A., 2007, 'The development of pastoral narrative mentorship principles as effective learning approach', Acta Theologica 27(2) 92-104.

Frazier, T., 2015, 'The result of fatherlessness in South Africa', viewed 20 June 2017, from http://www.tumifrazier.com/fatherlessness-in-south-africa/ 
Freeks, F.E., 2004 'Die rol van die ontbrekende vaderfiguur in die Suid-Afrikaanse konteks. 'n Prakties-teologiese studie', MA.-verhandeling, PU vir CHO, Potchefstroom.

Freeks, F.E., 2007, "n Karakterbou program vir verdere onderwys- en opleidingskolleges', PhD-proefskrif, Noordwes-Universiteit, Potchefstroom.

Freeks, F.E., 2011, 'The role of the father as mentor in the transmission of values: A pastoral-theological study', PhD thesis, North-West University, Potchefstroom.

Freeks, F.E., 2017, 'Responses of adolescents regarding the indispensable role of the Christian father as mentor within the family: A qualitative study', In die Skriflig 51(1), a2255. https://doi.org/10.4102/ids.v51i1.2255

Freeks, F.E. \& Lotter, G.A., 2009, "n Praktiese-teologiese ondersoek na die uitwerking van afwesige vaders: ' $n$ verkennende kwalitatiewe ondersoek in die Promosagemeenskap', Koers 74(3), 519-534. https://doi.org/10.4102/koers.v74i3.136

Goeke-Morey, M.C. \& Cummings, E.M., 2007, 'Impact of father involvement: A closer look at indirect effects models involving marriage and child adjustment', Applied Development Science 11(4), 221-225. https://doi.org/10.1080/1088869070 1762126

Goodsell, T.L. \& Meldrum, J.T., 2010, 'Nurturing fathers: A qualitative examination of child-father attachment', Early Child Development and Care 180(1\&2), 249-262. https://doi.org/10.1080/03004430903415098

Greeff, M., 2005, 'Information collection: Interviewing', in A.S. de Vos, H. Strydom, C.B. Fouché \& C.S.L. Delport (eds.), Research at grass roots for the social sciences and human service professions, pp. 286-313, Van Schaik, Pretoria.

Hawkins, C., 2015, 'Most SA households run by single moms', SA Breaking News, 3 September, viewed 20 June 2017, from http://www.sabreakingnews.co. 3 September, viewed 20 June 2017, from http://ww
za/2015/09/03/most-sa-households-run-by-single-moms/

Heenan, J., 2004, 'Cornerstone values - A New Zealand values education initiative', viewed 01 March 2018, from http://cornerstonevalues.org/

Herman, L. \& Mandell, A., 2004, From teaching to mentoring: Principle and practice, dialogue and life in adult education, Routledge Falmer, London.

Janse van Rensburg, J., 2009, Seminar on research methodology, 30-31 August, Potchefstroom, Faculty of Theology, North-West University (Unpublished).

Johnson, W.B. \& Ridley, C.R., 2004, The elements of mentoring, Palgrave Macmillan, New York.

Klopper, H., 2008 'The qualitative research proposal', Curationis 31(4), 62-72. https:// doi.org/10.4102/curationis.v31i4.1062

Krampe, E.M. \& Newton, R.R., 2006, 'The father presence questionnaire: A new measure of the subjective experience of being fathered', Fathering 4(2), 159-190, Spring. https://doi.org/10.3149/fth.0402.159

Krefting, L., 1991, 'Rigor in qualitative research: The assessment of trustworthiness', American Journal of Occupational Therapy 45(3), 214-221. https://doi.org/ 10.5014/ajot.45.3.214

Lotter, G.A., 2007, 'Pastorale Teologie: voëlvlug en (voorlopige) landing', NWU, Potchefstroom. (Wetenskaplike bydraes, Reeks H: Intreerede nr. 185. 29 Oktober 2004).

Lotter, G.A., 2010, 'E-mentoring as effective tutoring tool in higher education', pape presented at the Mentoring Conference, Durban, 2-5 September.

Masango, M., 2011, 'Mentorship: A process of nurturing others', HTS Teologiese Studies/Theological Studies 67(1), Art. \#937, 5 pages. DOI: 10.4102/hts.v67i1.937

McGraw, P., 2004, Family first: Your step-by-step plan for creating a phenomenal family, Free Press, New York.

Megginson, D., Clutterbuck, D., Garvey, B., Stokes, P. \& Garret-Harris, R., 2006, Mentoring in action: A practical guide, Kogan Page, London.

Mkhize, V., 2013, 'Black, young poor and fatherless', Star, 19 November, p. 2.

Mouton, J. \& Marais, D.C., 1992, Basic concepts in the methodology of social sciences, R.G.N., Pretoria.

Mulaudzi, F.M., Libster, M.M. \& Phiri, S., 2009, 'Suggestions for creating a welcoming nursing community: Ubuntu, cultural diplomacy, and mentoring', International Journal for Human Caring 13(2), 45-51. https://doi.org/10.20467/1091-5710. 13.2.45

Munroe, M., 2008, The fatherhood principle: Priority, position, and the role of the male, Whitaker House, New Kensington.
Neuman, W.L., 2003, Social research methods: Qualitative and quantitative approaches, 5th edn., Allyn \& Bacon, Boston, MA.

Olsen, S., 2007, 'Daddy come home: Evangelicalism, fatherhood and lessons for boys in late nineteenth-century Britain', Fathering 5(3), 174-196. https://doi.org/ $10.3149 /$ fth.0503.174

Palkovitz, R., 2007, 'Challenges to modelling dynamics in developing a developmental understanding of father-child relationships', Applied Developmental Science 11(4) 190-195. https://doi.org/10.1080/10888690701762050

Perrin, P.B., Baker, J.O., Romelus, A.M., Jones, K.D. \& Heesacker, M., 2009 'Development, validation, and confirmatory factor analysis of the father hunger scale', Psychology of Men \& Masculinity 10(4), 314-327. https://doi.org/10.1037/ a0017277

Pinkoane, M.G., 2005, 'Incorporation of traditional healers into the national health care delivery system', PhD thesis, North-West University, Potchefstroom.

Pleck, J.H., 2007, 'Why could father involvement benefit children? Theoretical perspectives', Applied Development Science 11(4), 196-202. https://doi.org/ perspectives', Applied Develop
10.1080/10888690701762068

Rens, J.A., 2005, 'Riglyne vir waarde-opvoeding in Suid-Afrikaanse skole', PhD.proefskrif, Noordwes-Universiteit, Potchefstroom.

Rudney, G.L. \& Guillaume, A.M., 2003, Maximum mentoring: An action guide for teacher trainers and cooperating teachers, Corwin Press, Thousand Oaks, CA

Scalise, E., 2010, 'Family systems theory, interventions and techniques', Christian Counselling Today 18(2), 53-54.

Seutter, R.A. \& Rovers, M., 2004, 'Emotionally absent fathers: Furthering the understanding of homosexuality', Journal of Psychology \& Theology 32(1), 43-49. https://doi.org/10.1177/009164710403200105

Steytler, J.P.D., 2007, 'Mentorskap in die maatskaplike funksionering van die seun in sy laat-middelkinderjare', MA.-verhandeling, Noordwes-Universiteit, Potchefstroom

Struwig, F.W. \& Stead, G.B., 2001, Planning, designing and reporting research, Maskew Miller Longman, Cape Town.

Strydom, H., 2005, 'The pilot study', in A.S. de Vos, H. Strydom, C.B. Fouché \& C.S.L. Delport (eds.), Research at grass roots: For the social sciences and human service professions, 3rd edn., Van Schaik, Pretoria.

Strydom, H. \& Delport, C.L.M., 2004, 'Research at grass roots: For social sciences and human service professions', in A.S. de Vos (eds.), Research at grass roots for the social sciences and human service professions, p. 493, Van Schaik, Pretoria.

Thorne, S., 2008, Interpretive description, Left Coast Press, Walnut Creek, CA.

Tucker, K., 2007, Establishing a mentoring and coaching programme, Knowres, Randburg.

Vaughan, J., 2010, 'Dads and the daughters they love', viewed 20 June 2017, from http://www.focusonthefamily.ca/parenting/fatherhood/dads-and-the-daughtersthey-love

Wall, J., 2007, 'Fatherhood, childism, and the creation of society', Journal of the American Academy of Religion 75(1), 52-76. https://doi.org/10.1093/jaarel/Ifl059

Waresak, J.T., 2016, '5 keys to lead your wife' i.e. 'Wear the pants', viewed 20 June 2017, from http://www.drjamesdobson.org/blogs/the-fatherhood-challenge/thefatherhood-challenge/2016/06/22/5-keys-to-lead-your-wife-ie-wear-the-pants

Warren, R.C., 2005, 'Our fathers who are on earth: If Satan thinks they are a key battleground, shouldn't we?', Christianity Today 49(5), 53.

Willerton, E., Schwarz, R.L., Macdermid, J., Wadsworth, S.M. \& Oglesby, M.S., 2011 'Military fathers' perspectives on involvement', Journal of Family Psychology 25(4), 521-530. https://doi.org/10.1037/a0024511

Williams, A., 2008, 'We badly need good fathers', Human Events 64(21), 18, June.

Williams, R.B., 2014, 'The male identity crisis and the decline of fatherhood', Psychology Today, viewed 20 June 2017, from http://www.psychologytoday.com/ em $/ 152400$

Wong, M.S., Mcelwain, N.L. \& Halberstadt, A.G., 2009, 'Parent, family, and child characteristics: Associations with mother-and father-reported emotion socialisation practices', Journal of Family Psychology 23(4), 452-463. https://doi.org/10.1037/ a0015552

Wood, J.T. \& Duck, S., 2006, Composing relationships: Communication in everyday life, Thomson Wadsworth, Belmont, CA. 